\title{
DIGITAL MAPPING OF THE NORDAUSTLANDET ICE CAPS FROM AIRBORNE GEOPHYSICAL INVESTIGATIONS
}

by

\author{
J.A. Dowdeswell, D.J. Drewry, A.P.R. Cooper and M.R. Gorman
}

(Scott Polar Research Institute, University of Cambridge, Cambridge CB2 1ER, U.K.)

and

\author{
O. Liestøl and O. Orheim
}

(Norsk Polarinstitutt, P.O. Box 158, 1330 Oslo Lufthavn, Norway)

\begin{abstract}
Airborne geophysical investigations of the previously little-studied Nordaustlandet ice caps $\left(11150 \mathrm{~km}^{2}\right)$ took place in 1983, using SPRI $60 \mathrm{MHz}$ radio echo-sounding (RES) equipment of $160 \mathrm{~dB}$ system performance. RES and navigational data were recorded digitally. Navigation used a ranging system (accurate to $\pm 30 \mathrm{~m}$ ) from aircraft to ground-based transponders, located by satellite geoceivers, supplemented by the aircraft's navigational instruments and timed crossings of known features. Ice surface and bedrock elevations were measured, using aircraft pressure altitude, terrain clearance, and ice thickness data. The mean error of 251 crossing points on Austfonna was $11 \mathrm{~m}$. The reduced geophysical data are stored on a direct-access computer database. During $3400 \mathrm{~km}$ of flying, Austfonna $\left(8105 \mathrm{~km}^{2}\right)$ was covered by traverses a nominal $5 \mathrm{~km}$ apart, whereas a $15 \mathrm{~km}$-spaced grid was flown over Vestfonna $\left(2510 \mathrm{~km}^{2}\right)$. Maps of ice surface morphology and subglacial, bedrock topography were produced for Austfonna and Vestfonna, along with an ice thickness map of Austfonna. Austfonna reaches a maximum surface elevation of $791 \mathrm{~m}$ and ice thickness of $583 \mathrm{~m} .28 \%$ of the bedrock area beneath Austfonna lies below sea level. RES yielded bedrock echoes for $91 \%$ of track over Austfonna, but only $52 \%$ over Vestfonna. This was probably due to warmer conditions on Vestfonna, resulting in greater absorption and scattering of electro-magnetic energy. Ice surface elevations are a principal data source in the revision of official Norwegian maps of Nordaustlandet.
\end{abstract}

\section{INTRODUCTION}

The several ice caps on Nordaustlandet in Svalbard (Fig.1), covering an area of $11150 \mathrm{~km}^{2}$, represent one of the largest glacierized areas outside the Antarctic and Greenland ice sheets. They are of sub-polar thermal regime, and are of particular interest because several drainage basins have been observed to surge; that of Brásvellbreen having undergone the largest event of this type so far recorded (Schytt, 1969). In addition, the ice caps represent an ice-covered area of logistically manageable extent, which may be used as an analogue in studies of the dynamics of large ice masses. For these reasons, the Nordaustlandet ice caps were selected for long-term field investigation and modelling studies. Little previous glaciological information was available, however, concerning these ice caps; the accumulation and seismic ice-thickness measurements of the Swedish IGY Expedition representing the most comprehensive existing data set (Schytt, 1964; Ekman, 1971).

A preliminary season of radio echo-sounding (RES) on Spitsbergen glaciers, in 1980, showed that the Scott Polar Research Institute (SPRI) Mk.IV $60 \mathrm{MHz}$ radar was suitable for sounding in Svalbard (Dowdeswell and others, 1984a, 1984b). A field programme of airborne geophysical work, including aircraft altimetric and RES data collection, was therefore undertaken in spring 1983, to obtain a

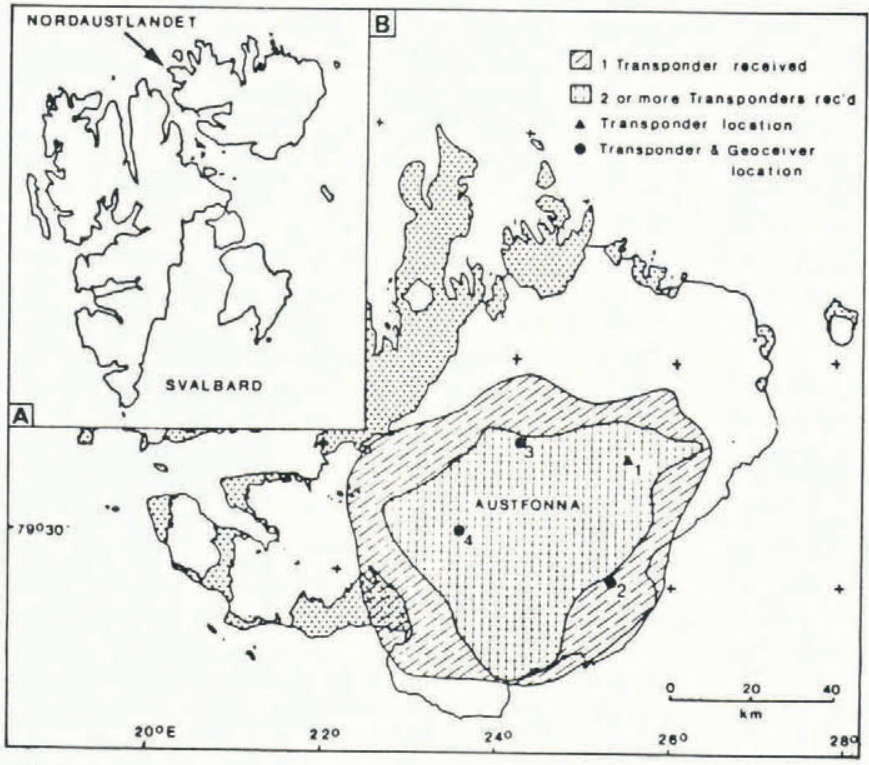

Fig.1. (a) Location of Nordaustlandet within Svalbard. (b) Location of transponders and geoceivers on Austfonna and the area over which the aircraft received range information from transponders. Dotted areas indicate ice-free land.

comprehensive data set on ice surface and bedrock morphology and ice thickness over the ice caps of Nordaustlandet. This paper presents (1) the methods of digital data acquisition used, together with an analysis of errors and (2) the results, in the form of detailed maps of the ice surface, subglacial topography, and ice thickness of the Nordaustlandet ice caps.

\section{METHODS OF DIGITAL MAPPING}

\section{SPRI Mk IV Radar and Digital Recording System}

An SPRI Mk. IV pulse-modulated radar system, operating at a centre frequency of $60 \mathrm{MHz}$, was used during the 1983 field season. This equipment is a modified version of the $35 \mathrm{MHz}$ SPRI Mk. II apparatus described by Evans and Smith (1969). A short pulse length of $300 \mathrm{~ns}$ and a logarithmic receiver with bandwidth of $15 \mathrm{MHz}$ were used. System performance, the ratio of peak power output to receiver input noise, was $160 \mathrm{~dB}$. Antenna gain and the effects of digital integration are not included in the value given for system performance. A de Havilland Twin Otter fixed-wing aircraft was used for RES in Svalbard. Simple dipole antennae were mounted under either wing, one for transmitting and the other for receiving. Antenna forward gain was $8.3 \mathrm{~dB}$. 
The digitization and recording of radio-echo pulses was controlled by a Z-80 based micro-computer, which also handled the recording of navigational data. Both radar and navigational information were collected at the same time and were recorded contiguously on magnetic tape. Data cartridges (conforming to International Standards Organization No. 4057), holding $3.2 \mathrm{M}$ bytes of data (c. $5 \mathrm{hr}$ of airborne RES), were used to record data on tape in the aircraft. The data were then transferred to standard 1600 bpi, 9-track, magnetic tape, prior to further reduction.

During airborne RES, data were recorded at two-second intervals. The mean of 8 ' $A$ ' scopes (i.e. displays of log. returned power against time range), spaced uniformly over a one-second interval (c. $60 \mathrm{~m}$ along-track), was recorded. This method of data recording reduced system noise through its integrating effect, increasing signal-tonoise ratio by $4.5 \mathrm{~dB}$. The other second of each two-second cycle was spent writing this information, together with the navigational data, to tape. The micro-computer digitized each 'A' scope as 256 points, spaced at 100 ns intervals, giving a total time scale of $25.6 \mu \mathrm{s}$. This is equal to 2150 $\mathrm{m}$ in ice, using a value of $168 \mathrm{~m} \mathrm{\mu s}^{-1}$ for the velocity of radio waves in that medium. The nominal accuracy of the system was therefore 100 ns. Fractions of that interval could, however, be defined by interpolation to give improved time resolution. This interpolation procedure is valid because the pulse length of the SPRI Mk. IV system is $300 \mathrm{~ns}$, and a digitization interval of $100 \mathrm{~ns}$ is therefore above the Nyquist frequency. The interpolation of the position of the leading edge of the surface return is accurate to approximately $2 \mathrm{~m}$, in air. The received, analogue signal was also displayed continuously on an oscilloscope in the 'A' mode and the digitized signal was displayed in real time on a small cathode ray tube in either ' $A$ ' or ' $Z$ ' mode, to provide a check on the functioning of the radar system. A Honeywell oscillographic recorder also provided back-up analogue ' $Z$ ' scopes on heat-sensitive paper in near real time (a 3 minute lag).

\section{Navigation on the Nordaustlandet Ice Caps}

Aircraft navigation over the Nordaustlandet ice caps used three main data sources: (1) a Motorola ranging system from the aircraft to a network of ground-based transponders, which were located accurately on the ice surface by satellite geoceiver measurements; (2) the aircraft's own navigational instruments, which gave a calculated latitude and longitude after processing by the on-board Tactical Air Navigation System (TANS) computer; and (3) timed crossings of known features on the ground (e.g. the termini of outlet glaciers).

The Motorola microwave distance-measuring system used an on-board transmitter/receiver and micro-computer, to calculate the distance of the aircraft from four ground-based transponders (Fig.lb). The maximum operating range of the transponders was approximately $40 \mathrm{~km}$. Some difficulties were experienced, however, in ensuring a clear line of sight between the transponders and the aircraft, owing to their narrow vertical beamwidth and obstructing ice-surface topography. In particular, transponder range northwards from stations 1 and 3 (Fig.1b) was limited by the proximity of the main ice divide on Austfonna. Even so, 35\% of Austfonna (sensu Dowdeswell and Drewry, 1985) was within range of two or more transponders, while ranges from one or more transponders were received over $61 \%$ of the ice cap (Fig.1b).

To calculate the position of the aircraft, the absolute position of at least two transponders must be known accurately. The latitude and longitude of transponders 2,3 and 4 was, therefore, measured by satellite geoceivers, set up by a ground party (Fig.1b). The accuracy of each geoceiver position was $\pm 2 \mathrm{~m}$ and the location of each transponder, relative to the geoceiver antenna, was measured by theodolite and electronic distance measurer. For logistical reasons, no geoceiver was located at transponder 1 , but its position was found by calculating the location of the aircraft at a number of points, where transponders 1, 2 and 3 were giving signals. Transponders 2 and 3 were used to locate the aircraft, while the intersections of several distance measurements to transponder 1 were used to find the latter's latitude and longitude. Where the aircraft was within range of three or more transponders, range errors of less than $\pm 30 \mathrm{~m}$ were measured. This value defines the operational accuracy of the Motorola system.

The aircraft's other navigational instruments were used to supplement the transponder-derived data. The on-board TANS computer took dead-reckoning and air data (air speed, altitude, and temperature) to calculate aircraft latitude and longitude. Due to failure of the Doppler navigation system, however, these data contained large errors in absolute location, resulting from the effect of wind. The dead-reckoning and air data were therefore controlled by absolute fixes from timed crossings of known points and transponder ranging data, where available. Navigational accuracy over Nordaustlandet was thus not uniform. Errors were calculated as $\pm 30 \mathrm{~m}$, where fixes from two or more Motorola transponders were available over parts of Austfonna (Fig.1b) and were estimated as $\pm 250 \mathrm{~m}$ in other areas of that ice cap, together with the whole of Vestfonna.

Navigational data from the TANS computer and from each Motorola transponder were recorded on magnetic tape aboard the aircraft. The reduction of these data and the insertion of fixes, utilizing the position of known points on the ground, was carried out on an IBM 3081 computer.

\section{Ice Cap Surface and Bedrock Elevations}

To calculate ice cap surface and bedrock elevations above sea level, data derived from both the aircraft's instruments and the SPRI Mk. IV RES equipment were used. Hence:

$$
\begin{aligned}
& \mathrm{S}_{\mathrm{e}}=\mathrm{P}_{\mathrm{a}}-\mathrm{T}_{\mathrm{c}} \\
& \mathrm{B}_{\mathrm{e}}=\mathrm{P}_{\mathrm{a}}-\mathrm{T}_{\mathrm{c}}-\mathrm{h}
\end{aligned}
$$

where $\mathrm{S}_{\mathrm{e}}$ and $\mathrm{B}_{\mathrm{e}}$ are surface and bedrock elevations ( $\mathrm{m}$ a.s.1.), $\mathrm{P}_{\mathrm{a}}$ is pressure altitude, $\mathrm{T}_{\mathrm{c}}$ is aircraft terrain clearance, and $\mathrm{h}$ is ice thickness. Pressure altitude was measured by the aircraft pressure altimeter, to an accuracy of $\pm 2 \mathrm{~m}$. Aircraft terrain clearance and ice thickness data both came from the reduction of digital RES data. The aircraft was fitted with its own radar altimeter but, although information from this instrument was recorded, terrain clearance data from the SPRI Mk. IV radar were preferred, because they were less noisy than those from the former instrument (Fig.2). The close correspondence between the pressure altimeter data and SPRI Mk. IV terrain clearance measurements of the sea surface in Figure 2 also implies that any aircraft oscillations were removed in the calculation of surface elevation (equation 1). Absolute aircraft altitude was obtained by fixing pressure altimeter readings to sea level over $2-4 \mathrm{~km}$ sections of open water or floating fast ice. The longest interval between fixing the pressure altimeter over sea was approximately 45 minutes and was usually significantly less than this, thus reducing the effects of any variations in the pressure surface.

To calculate ice surface and bedrock elevations, aircraft terrain clearance and ice thickness were extracted from the raw, digital RES data. The time delay to the first return of ice surface and bedrock echoes during a two-second recording cycle was identified, using simple tracking routines. The raw data were differentiated (Fig.3a), to emphasize the surface and bed echoes, and the tracking routine searched downwards through the 256 data points, recorded during each data-gathering cycle, until a positive value for differentiated, returned power was located (i.e. a change from decreasing power to increasing power). Interpolation, within the appropriate $100 \mathrm{~ns}$ interval, then took place to identify the precise position of the leading edge of the echo. The first rise in the gradient of returned signal represented the ice surface, while a second rise (where present) indicated the position of bedrock. Internal layer echoes, similar to those reported by Dowdeswell and others (1984b), were not normally noted on differentiated records from the Nordaustlandet ice caps. Data from the next two-second cycle were then examined, but this time only the three (surface) or five (bedrock) $100 \mathrm{~ns}$ intervals, either side of the previous position, were searched for returns. If 


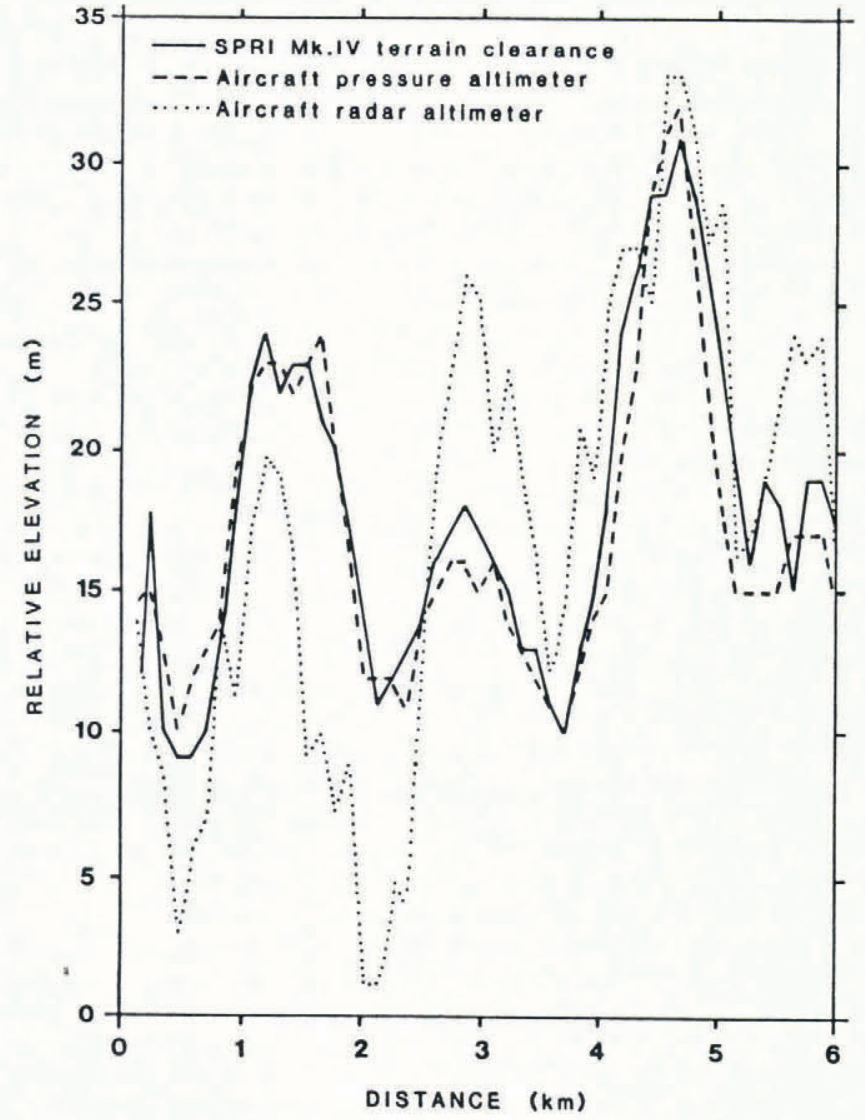

Fig.2. SPRI Mk. IV terrain clearance, aircraft radar altimeter and aircraft pressure altimeter elevation data, collected over sea off Nordaustlandet. Relative elevations are shown for ease of comparison.
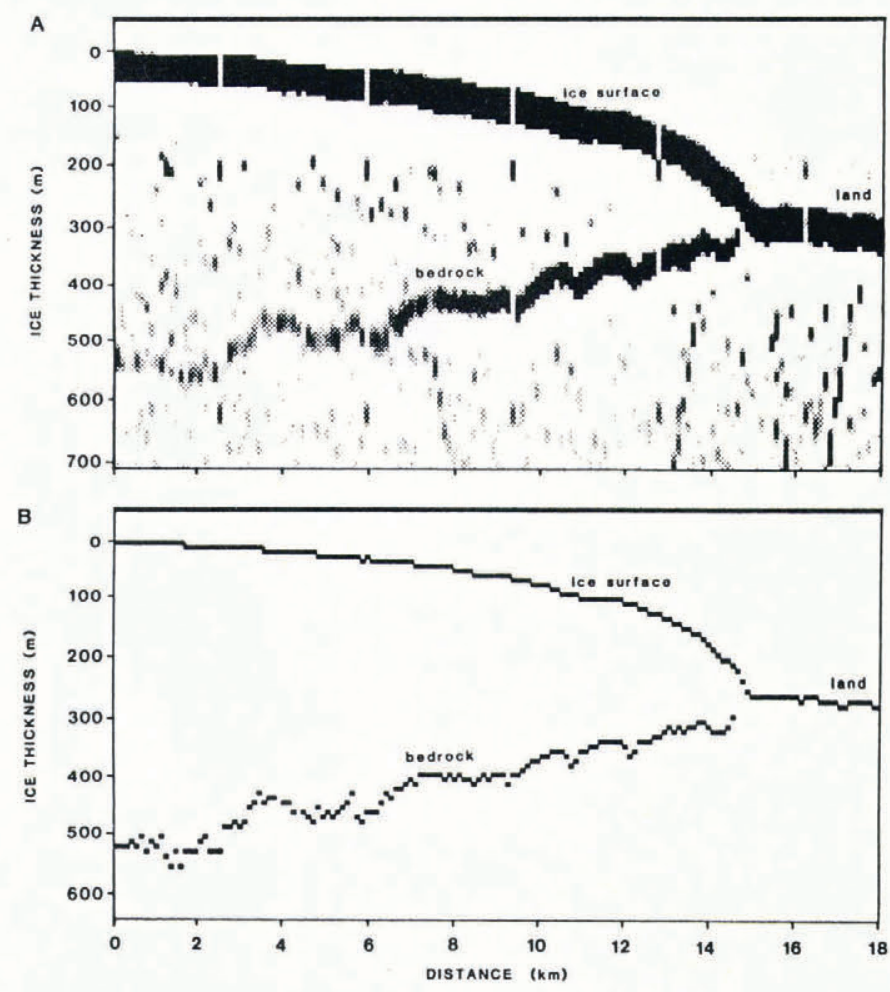

Fig.3. (a) Differentiated, digital RES data in the ' $Z$ ' mode, collected over Austfonna. Increasing pixel density indicates an increase in the gradient of returned power. (b) Results of surface and bedrock tracking of the digital data. track was lost, the routine restarted at the top of the data column. This approach was adequate for tracking the relatively smoothly-varying ice surface. However, a manual restart facility was needed to track the bed in certain areas, because it was more uneven and returned less power than the ice surface (Fig.3a). The results of surface and bedrock tracking of a short section of RES on Austfonna are shown in Figure 3b. All automated surface and bedrock tracking was checked manually by superimposing the results of tracking (Fig.3b) on the differentiated ' $\mathrm{Z}$ ' record (Fig.3a).

Applying pressure altitude, aircraft terrain clearance and ice thickness data to equations 1 and 2 , ice surface and bedrock elevations were calculated. These data were then treated with a low-pass filter of $0.5 \mathrm{~km}$ cut-off because this distance represented a broad approximation to the size of the RES footprint at the terrain clearances typically flown. Noise in both surface and bedrock data was therefore reduced, while the choice of a filter cut-off distance, approximating the radar footprint, meant that little real variation in surface and bedrock topography was removed.

After data reduction was completed, RES results were stored on disc as a direct-access database on an IBM 3081 computer (Cooper and others, 1983). The following information on airborne RES of Nordaustlandet can be retrieved for any specified time interval during each of the five missions flown: latitude, longitude, ice surface elevation, bedrock elevation, and cumulative distance into a mission. Aircraft terrain clearance, ice thickness and pressure altitude (corrected to sea level) are also retrievable, although forming a part of the reduction process themselves.

The differences in surface elevation, at points where flight lines cross, was also examined, in order to provide an estimate of the total magnitude of errors in surface elevation over Nordaustlandet. On Vestfonna, 14 crossing points were present, with a mean error of $9.9 \mathrm{~m}$ and standard deviation of $7.5 \mathrm{~m}$. In flights over Austfonna, there were 251 crossing points, with a mean error of 11.2 $\mathrm{m}$ and standard deviation of $9.3 \mathrm{~m}$. The higher mean errors and standard deviations for Austfonna were a result of several crossing points with errors above $40 \mathrm{~m}$. These occurred in areas of steep ice surface slopes, where even small navigational inaccuracies led to large crossing-point errors.

The crossing-point errors reported above subsume the following sources: (1) pressure altimeter calibration errors $( \pm 2 \mathrm{~m}) ;(2)$ errors in interpolating the position of the leading edge of the surface return $( \pm 2 \mathrm{~m})$; (3) variations in the pressure surface between pressure altitude fixes over the sea; and (4) navigational errors. Navigational errors of up to $\pm 250 \mathrm{~m}$ over much of the Nordaustlandet ice caps probably account for a relatively large proportion of total crossing-point error.

\section{GLACIOLOGICAL RESULTS}

\section{Radio Echo-Sounding Flight Lines}

Airborne RES of the ice caps of Nordaustlandet was carried out during five missions between 23 and 28 April, 1983 (Drewry and Liestøl, 1985). On-station flying over glacier ice in Nordaustlandet was carried out at a nominal velocity of $115 \mathrm{kts}\left(210 \mathrm{~km} \mathrm{hr}^{-1}\right)$. During airborne traverses across the ice caps, the aircraft normally flew between 750 and $1000 \mathrm{~m}$ a.s.l., at a constant altitude, in order to minimize rapid pressure fluctuations which might affect pressure altimeter readings. However, because the ice cap surface ranged between sea level and approximately $800 \mathrm{~m}$ a.s.l., aircraft terrain clearance varied between 100 and $750 \mathrm{~m}$. During certain airborne traverses, which involved long intervals of flying over both low- and high-altitude parts of the ice caps, it was necessary to adjust the flying height of the aircraft. This was because, at large terrain clearances, the bottom echo was sometimes obscured by surface scattering, due to the relatively large $\left(100^{\circ}\right)$ antenna beamwidth. The minimum terrain clearance was controlled by the recovery time of the RES receiver. During the 5 missions, approximately $3400 \mathrm{~km}$ of RES data were obtained in $20.4 \mathrm{hr}$ of on-station flying over Nordaustlandet (Fig.4). This amounted to over 30000 geophysical data points. Most of Austfonna was covered by airborne traverses spaced a 


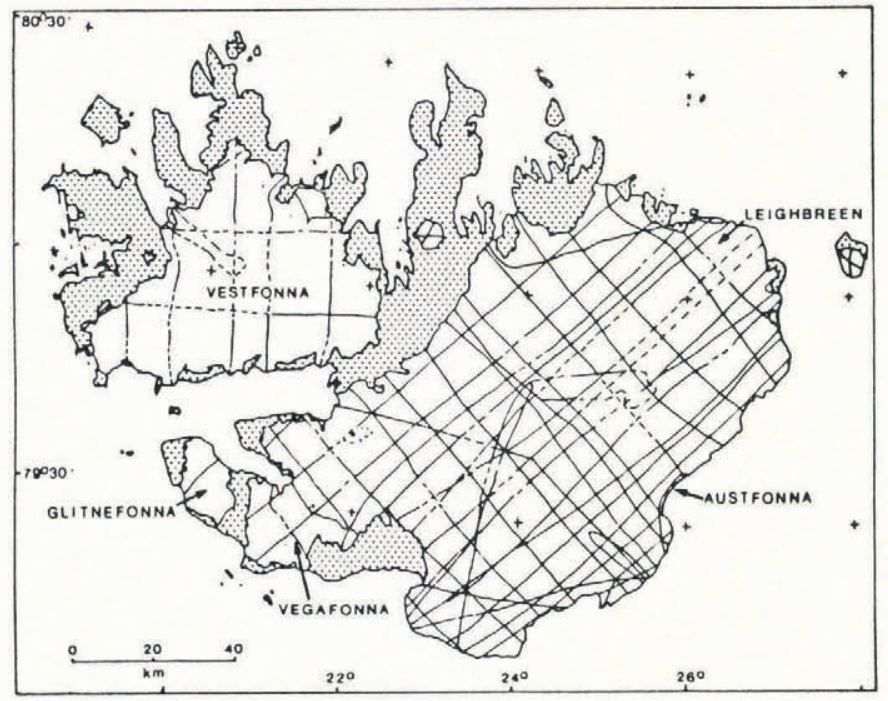

Fig.4. Aircraft flight lines over the Nordaustlandet ice caps. Dashed lines show where RES bedrock returns were not received.

nominal $5 \mathrm{~km}$ apart, whereas a $15 \mathrm{~km}$-spaced grid was flown over Vestfonna. Flight lines, diagonal to the main grid, were also inserted up flow lines in several drainage basins (Fig.4). The navigational methods, described above, were used to locate the flight lines shown in Figure 4 . The gently-curving nature of many of the traverses was due to the failure of the on-board Doppler navigation system. The pilots were therefore navigating by compass headings and visual contacts with known points, and some drifting due to cross-winds was relatively common.

\section{Ice Cap Surface Morphology}

Maps of the surface morphology of Austfonna and Vestfonna were produced with a contour interval of $50 \mathrm{~m}$, which is significantly in excess of the elevation errors, discussed above. Surface elevations on Austfonna are mapped in Figure 5. This map is based almost entirely on aircraft altimetric data from the flight lines in Figure 4. Landsat imagery and aerial photographs were used, however, to add detail in certain regions of relatively complex topography. Topographic features on Landsat imagery were digitized, fixed, and transformed to latitudes and longitudes, according to the procedure outlined in Dowdeswell and Cooper (1986). These accurately-located features were then used to shape the surface contours, defined from surface altimetric data, particularly in the areas between flight lines.

The $8105 \mathrm{~km}^{2}$ Austfonna has two main domes, which make up the summit areas Austdomen and Sørdomen (Dowdeswell and Drewry, 1985). Austdomen reaches a maximum, measured elevation of $791 \mathrm{~m}$ a.s.1., while the summit of Sørdomen is $683 \mathrm{~m}$ in altitude. The two domes are separated by a col, some $50 \mathrm{~m}$ lower than Sørdomen summit. A pronounced ice divide continues west of Sørdomen, marking the boundary between ice flowing north towards Wahlenbergfjorden and that moving south to Svartknausflya (Fig.5).

Several large outlet glaciers (e.g. Bråsvellbreen, Etonbreen (E)) form pronounced basins, which remain welldefined right to the main ice divide (Fig.5). Ice surface slopes generally become steeper with distance from this divide, but the widely-spaced contours in the terminal 25 $\mathrm{km}$ of Brásvellbreen indicate significant deviation from an equilibrium profile (Dowdeswell, 1984). A small, but pronounced, subsidiary ice dome (Isdomen) is also mapped as $I$ in Figure 5. Several other clearly-defined basins can also be observed in association with outlet glaciers draining the north side of Austfonna. The drainage basins of the Nordaustlandet ice caps are discussed in more detail in Dowdeswell and Drewry (1985).

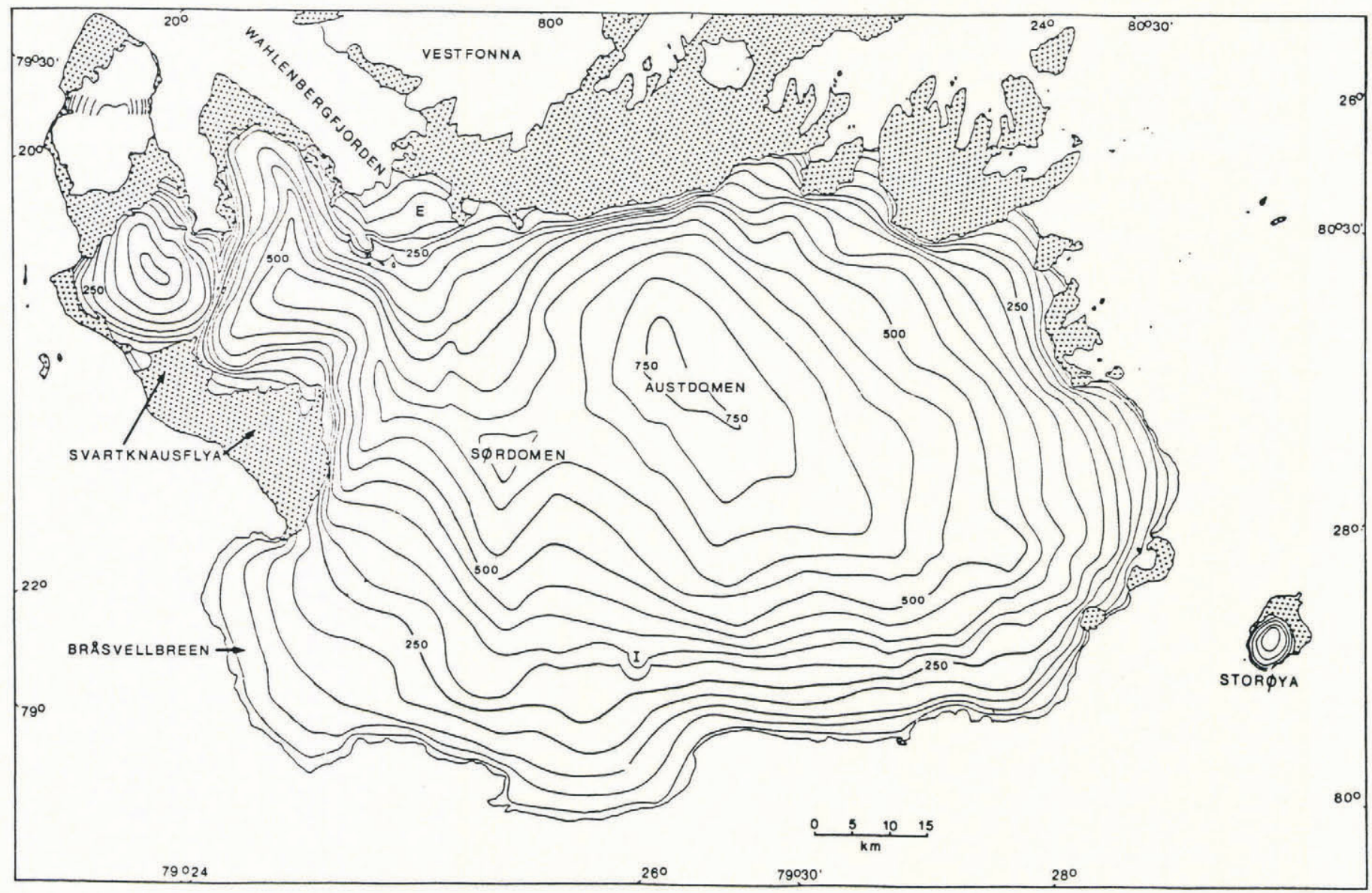

Fig.5. Ice surface elevations on Austfonna, Vegafonna, Glitnefonna, and Storøyjøkulen. Contour interval $50 \mathrm{~m}$. Dots indicate ice-free land. 


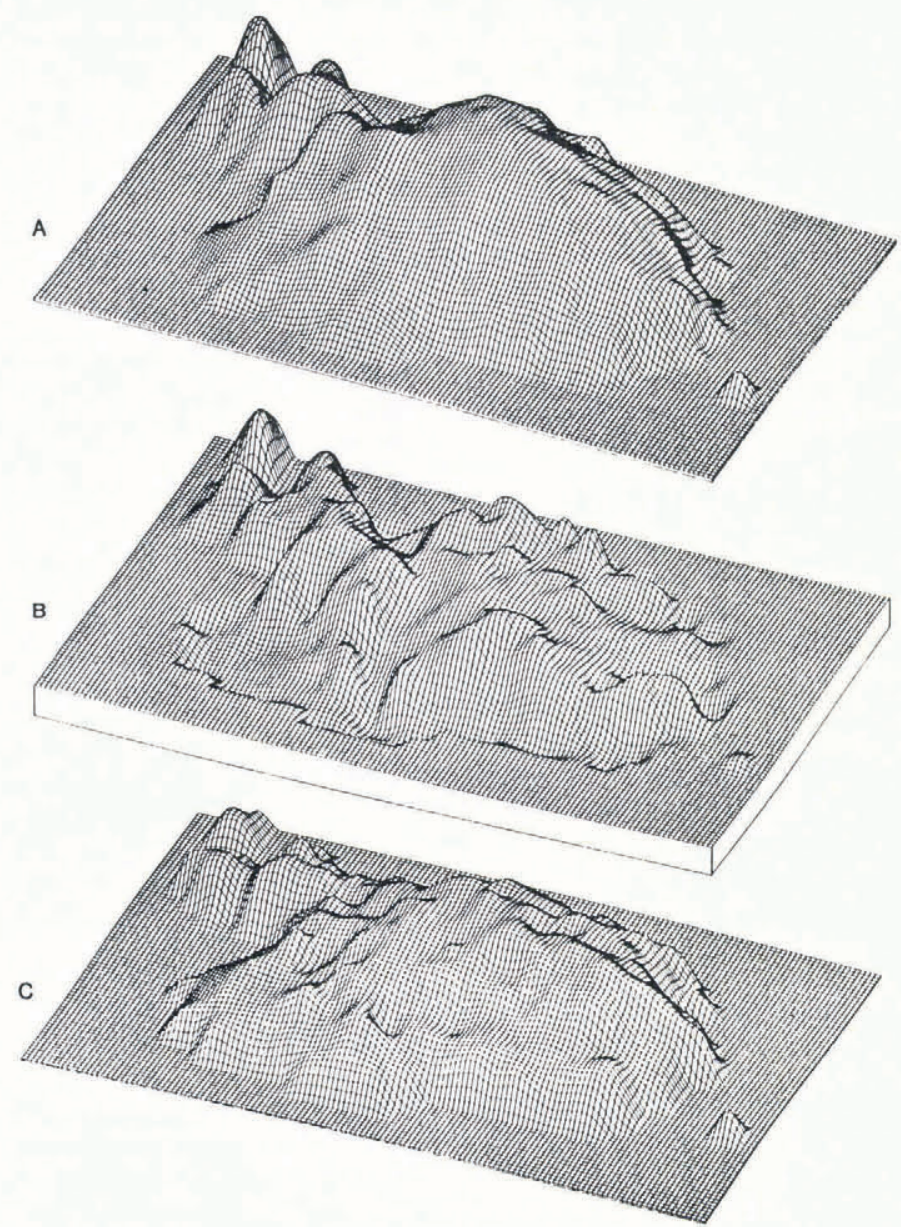

Fig.6. Isometric views from the east of Austfonna, Vegafonna, Glitnefonna and Storøyjøkulen (on the island at the right). (a) Ice surface, (b) subglacial bedrock, (c) ice thickness. Squares have $1.25 \mathrm{~km}$ sides and vertical scale is linear but arbitrary.

The surface morphology of Austfonna is also presented as an isometric plot in Figure 6a. The small ice caps of Vegafonna and Glitnefonna, together with Storøyjøkulen, on Storøya, are also illustrated. The isometric views provide a three-dimensional picture of the ice caps which shows their major surface features, viewed from the east (Fig.6).

The three smaller ice caps are contoured in Figure 5 and have very regular topography. This is not an artifact of the small number of flight lines that cross them (Fig.4), because their simple form was confirmed through the study of Landsat' imagery. Detail on the north side of Vegafonna has also been added from this additional data source. Contouring on Glitnefonna was restricted, because information from only one airborne traverse was available.

A $50 \mathrm{~m}$-interval contour map of the ice surface morphology of Vestfonna is presented in Figure 7. This ice cap, which has an area of $2510 \mathrm{~km}^{2}$, is significantly smaller than Austfonna. The less dense spacing of flight lines (Fig.4) precluded the computation of isometric views of Vestfonna, because an unacceptably large degree of interpolation would have been required.

The ice cap consists of a main ice divide of inverted ' $T$ ' shape, rising to a maximum elevation of approximately $620 \mathrm{~m}$ a.s.l. (Fig.7). Several minor ice domes are present on the ice cap and are related to high areas of the subglacial bedrock (Fig.9). Ice, draining south into Wahlenbergf jorden, some 20-25 km from the divide, consists of four welldefined outlet glaciers: Bodleybreen (B), Aldousbreen (A), Frazerbreen (Fr) and Idunbreen (I) (Fig.7). Additional detail, derived from the interpretation of Landsat imagery, has aided in shaping the contours associated with these outlet glaciers. Clearly-defined outlet glaciers also drain the north-east and western parts of Vestfonna (Fig.7). The two arms of Franklinbreen (F), in particular, form a major

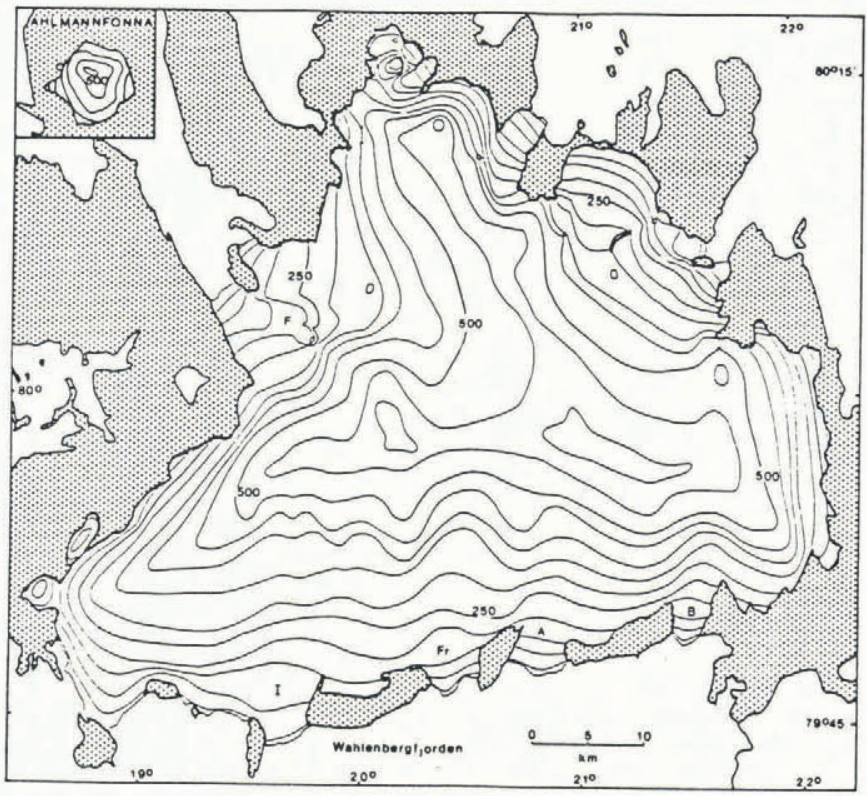

Fig.7. Ice surface elevations on Vestfonna and Ahlmannfonna (inset). Contour interval $50 \mathrm{~m}$. Dots indicate ice-free land.

basin on the west side of the ice cap, which separates two parts of the main ice divide. Landsat and aerial photographic evidence has aided the contouring of the relatively complex ice surface terrain in the most northerly part of Vestfonna (Fig.7). A contour map of Ahlmannfonna is inset in Figure 7 and, because only two intersecting flight lines cross this small ice cap, the position of its surface contours was refined using Landsat imagery.

These new maps of the surface of the Nordaustlandet ice caps (Figs. 5 and 7) will provide a principal data source for the complete revision of the existing of ficial Norwegian 1:500 000 and 1:1000000 scale maps of the island.

\section{The Spatial Distribution of Bedrock Returns}

While calibrated pressure altimetry and terrain clearance provide the main data source for the study of ice cap surface morphology, evidence on subglacial bedrock morphology and ice thickness comes from airborne RES data, collected in 1983. The spatial pattern of RES flight lines along which bedrock returns were absent is indicated in Figure 4. Bedrock echoes were not recorded for $48 \%$ of sounding over Vestfonna, but were absent over only some $9 \%$ of Austfonna. This indicates a qualitative difference between these two parts of Nordaustlandet, in terms of the ability of $60 \mathrm{MHz}$ radar equipment to resolve the glacier bed. Throughout Nordaustlandet, bed echoes were more of ten absent in the accumulation area than in the ablation zone (Fig.4). Given the sub-polar thermal regime of these ice caps (Schytt, 1969; Dowdeswell, 1984) and the problems encountered in RES in the accumulation areas of Spitsbergen glaciers (Dowdeswell and others, 1984a, 1984b), the disproportionate lack of bed returns from Vestfonna suggests that this ice cap contains more ice that is at or close to the melting point. Such warm ice will lead to both greater absorption and more internal scattering. The latter is associated with the presence of more internal inhomogeneities, for example ice lenses and water pockets. Available $10 \mathrm{~m}$ temperature data from Nordaustlandet supports this interpretation (Dowdeswell, 1984).

Bottom returns may remain undetected for two main reasons (Smith and Evans, 1972): (1) returned signal from that interface drops below the noise level of the receiver; and (2) scattering, which can be from discrete surface or internal inhomogeneities, masks bed echoes, even when they are relatively strong. An examination of ' $Z$ ' records from both digital and analogue sources showed that, in most areas of Austfonna, bedrock returns typically disappear gradually as they fall below the level of receiver noise, probably as 
signal attenuation increases, due to the presence of warmer and/or thicker ice. The drainage basin of Leighbreen (Fig.4) is an exception to this generalization and is discussed below. On Vestfonna, the reasons for the absence of bottom echoes are more varied. In some areas of the accumulation zone, returned power appears to fall below receiver noise while, in others, the bed return becomes obscured by internal scatter echoes. These discrete reflectors may be associated with warmer temperatures and less homogeneous firn and ice on Vestfonna.

Strong surface scattering is responsible for some areas where bed echoes are masked, particularly nearer the margins of the Nordaustlandet ice caps and on actively surging glaciers. A large area of heavy surface scattering is found on Leighbreen, where the bed is obscured on two long stretches of track up the basin (Fig.4). However, bedrock returns are absent from only one of the flight lines which are orthogonal to and intersect these two legs (Fig.4). An investigation of the terrain clearances at which these legs were flown demonstrates the nature of the problem. The tracks up Leighbreen without bed echoes (Fig.4) were flown at $390-450 \mathrm{~m}$ above the surface, but a cross-cutting leg flown at a terrain clearance of $145-165 \mathrm{~m}$ recorded bedrock returns. Thus, the bottom is increasingly likely to be lost as terrain clearance and, therefore, the size of the radar footprint increases, because the number of scatterers illuminated rises as the square of terrain clearance and scatter echoes are received over a longer time delay. On Austfonna, heavy surface scattering is confined largely to Leighbreen, where very large sastrugi and some crevassing were observed during flight. On Vestfonna, part of the bed of Bodleybreen is also marked by surface scattering from crevasses associated with surge activity.

\section{Bedrock Morphology under Austfonna and Vestfonna}

Bottom returns were obtained from over $90 \%$ of track flown over Austfonna (Fig.4). The elevation of subglacial bedrock is therefore mapped for the whole ice cap in Figure 8. A contour interval of $100 \mathrm{~m}$ was selected, in order to show the major trends in bedrock morphology. This is much greater than estimated errors of less than $\pm 20 \mathrm{~m}$ in absolute bedrock elevations. An isometric view of the bedrock beneath Austfonna is presented in Figure 6b.

Three features are particularly prominent in Figure 8 First, two bedrock ridges, rising to over $300 \mathrm{~m}$ a.s.l. and separated by a valley, reaching an elevation of approximately $150 \mathrm{~m}$, run west to east across Austfonna. The valley is also a marked feature on the isometric view from the east of Nordaustlandet (Fig.6b). Secondly, much of the bedrock underlying the south and east sides of the ice cap is below sea level, by up to $157 \mathrm{~m}$ (Fig.8). The isometric plots provide visual images of these depressions (Fig.6b). A total of $28 \%\left(2270 \mathrm{~km}^{2}\right)$ of the bedrock area beneath Austfonna is below sea level, including $57 \%$ of the Bråsvellbreen basin and $47 \%$ of Leighbreen. Thirdly, subglacial bedrock troughs are associated with several outlet glaciers and drainage basins of the ice cap.

Despite the observation that some $28 \%$ of the base of Austfonna lies below sea level, there is little evidence that glacier ice is floating. The following equation, describing the surface elevation above sea level (e) of an ice shelf, assumed to be in hydrostatic equilibrium (Crary and others, 1962), was applied to known ice thickness values (h) around the periphery of the Nordaustlandet ice caps:

$$
\left.\mathrm{e}=\mathrm{h}\left[1-\left(\rho_{\mathrm{i}} / \rho_{\mathrm{m}}\right)\right]-\mathrm{s}\left[\left(\rho_{\mathrm{s}}-\rho_{\mathrm{i}}\right) / \rho_{\mathrm{m}}\right)\right]
$$

where $s$ is the depth of low density firn and $\rho_{\mathrm{i}}, \rho_{\mathrm{m}}$ and $\rho_{S}$ are the densities of ice, sea water and snow. Everywhere, ice surface elevations were an order of magnitude greater than those predicted for an ice shelf, using equation 3 .

The morphology of the bedrock underlying Vestfonna is mapped in Figure 9. Bottom returns were received over only $52 \%$ of track flown and were seldom obtained from the central parts of the ice cap (Fig.4). The area is therefore contoured at $100 \mathrm{~m}$ intervals, with regions of uncertain bedrock elevation marked by dashed lines. Shading

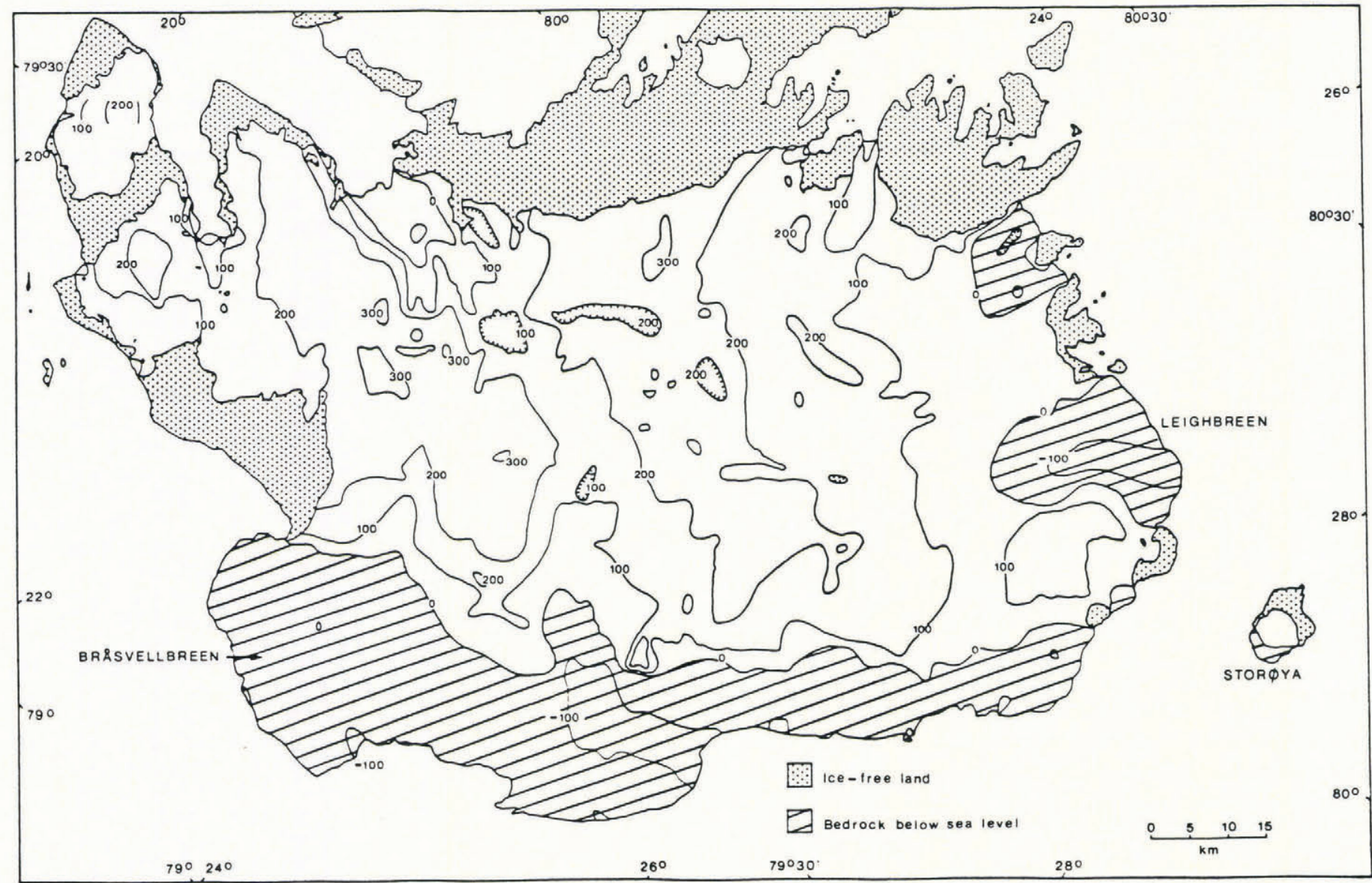

Fig.8. Subglacial bedrock elevations beneath Austfonna (contour interval $100 \mathrm{~m}$ ). 


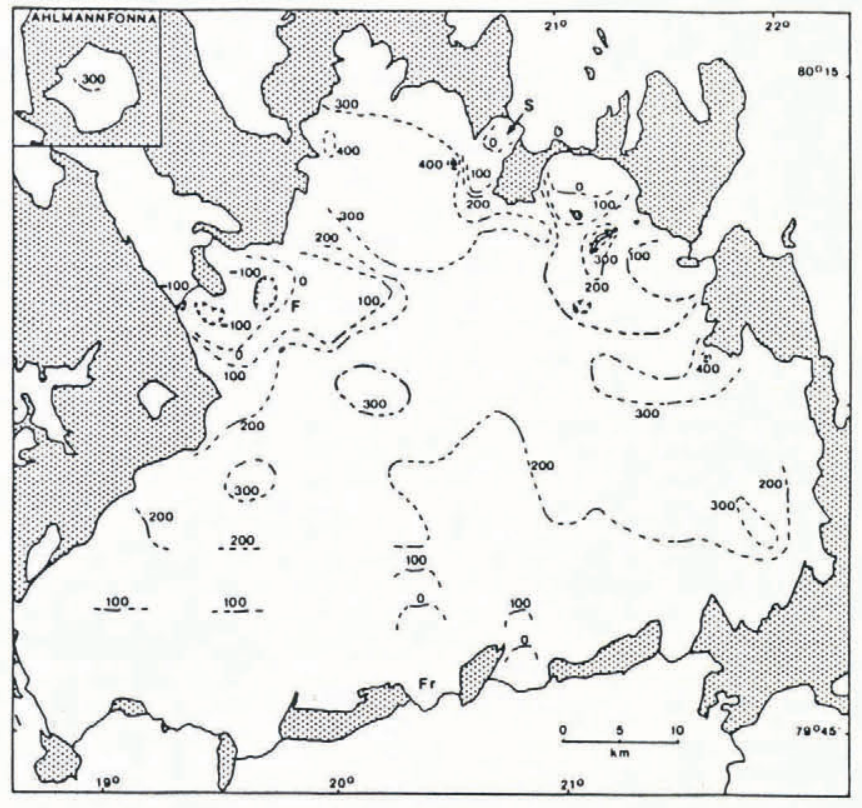

Fig.9. Subglacial bedrock beneath Vestfonna (contour interval $100 \mathrm{~m}$ ). Lines are dashed where contour position is uncertain.

is not applied to the highest and lowest parts of the bedrock, because of the discontinuous nature of bed echoes. A general description follows but, due to the relative lack of data, discussion is less detailed than for Austfonna.

Several areas of bedrock reach over $300 \mathrm{~m}$ a.s.l., including much of the north and parts of central and eastern Vestfonna and over half of Ahlmannfonna (inset in Fig.9). Bedrock troughs are found beneath the outlet glaciers Franklinbreen (F), Frazerbreen (Fr) and Sabinebreen (S) (Fig.9). Bedrock elevations dip below $-100 \mathrm{~m}$ near the margins of Franklinbreen. A smaller proportion of the subglacial bedrock of Vestfonna, as compared with Austfonna, is below sea level. This is expected, because the latter ice cap has ice cliffs over $130 \mathrm{~km}$ in length on its eastern, seaward margin, whereas Vestfonna is drained by a number of outlet glaciers, which are constrained topographically.

\section{Ice Thickness}

The ice thickness of Austfonna is mapped in Figure 10. Note that the $100 \mathrm{~m}$ thickness contour is not usually present, because the ice is generally of greater thickness, even at the ice cap margin. An isometric view of ice thickness is found in Figure 6c. The general trend is, as expected, for ice thickness to decrease towards glacier termini. A comparable map of Vestfonna has not been constructed, due to the relative lack of bedrock returns from that ice cap (Fig.4).

A relatively large area of ice, over $500 \mathrm{~m}$ thick (maximum $583 \mathrm{~m}$ ), coincides with the summit of Austfonna (Austdomen) and extends approximately $50 \mathrm{~km}$ to the north-east. Ice, $300-440 \mathrm{~m}$ thick, also parallels the ice surface divide west of Sørdomen and the eastern flank of Bråsvellbreen (Fig.10). The only region of the ice caps less than $100 \mathrm{~m}$ thick is at the western terminus of Brảsvellbreen, although even here the surface elevation is considerably greater than that predicted by equation 3 for a floating ice shelf of similar thickness. The seaward $20 \mathrm{~km}$ of Bråsvellbreen is almost all less than $300 \mathrm{~m}$ in thickness and corresponds to the ice lobe resulting from the surge observed in 1938 (Schytt, 1969). A submarine ridge, subparallel to, and approximately $3 \mathrm{~km}$ offshore from, the present terminus of Bråsvellbreen, probably marks the maximum extent of the surge (Solheim and Pfirman, 1985). It is assumed, because this basin is now in the quiescent phase between surges, that ice in this area is relatively inactive and thinning (c.f. Liestøl, 1969). Another area of particularly thin ice $(<200 \mathrm{~m})$ is found beneath Isdomen (I), located $10 \mathrm{~km}$ west of Hartogbukta (Fig.10).

Comparison with seismic measurements of ice thickness

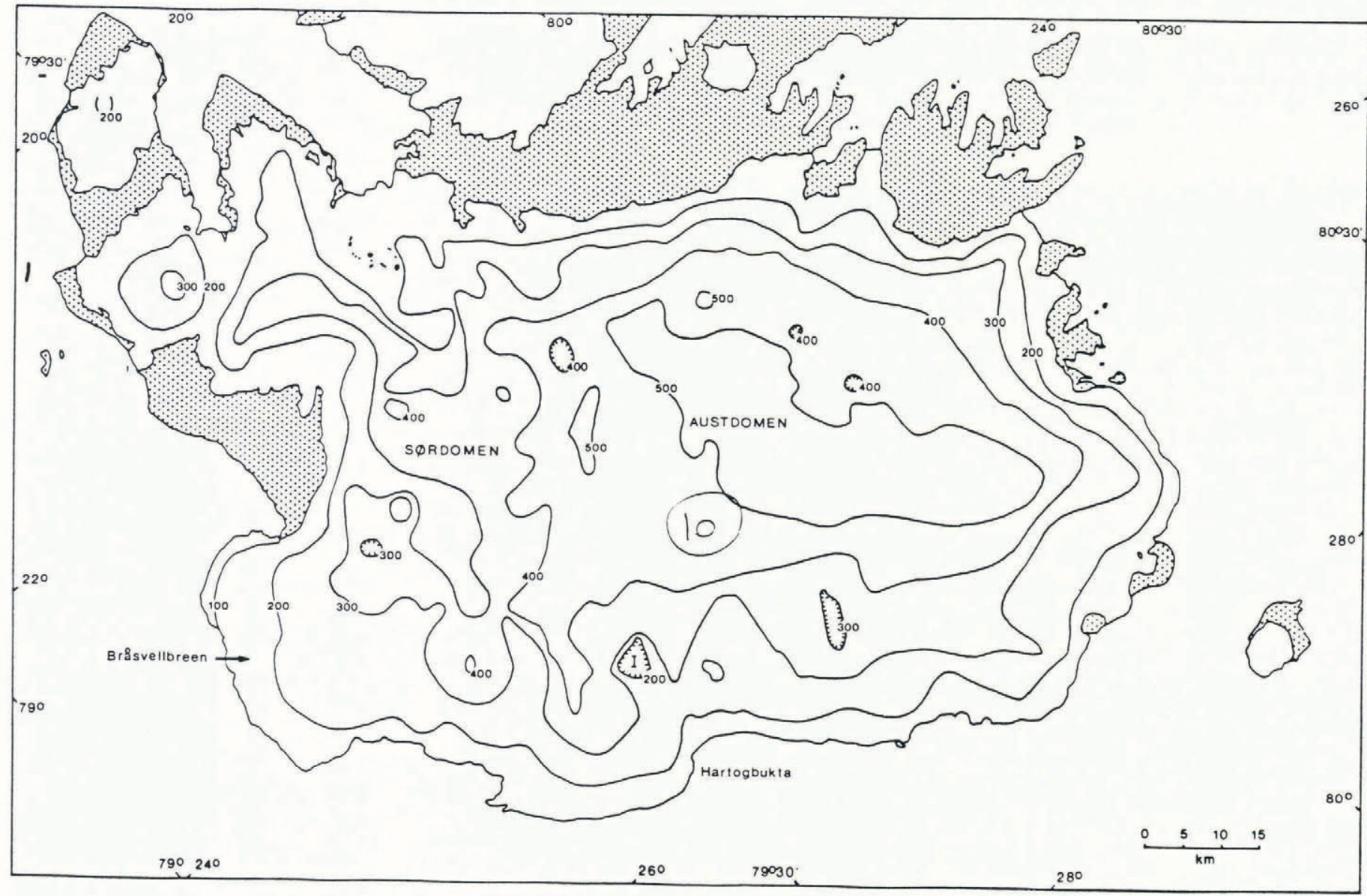

Fig.10. Thickness of ice making up Austfonna (contour interval $100 \mathrm{~m}$ ). 
on Austfonna (Ekman, 1971) shows differences that are usually less than $6 \%$ of ice depth. It is suggested that navigational inaccuracies of $<900 \mathrm{~m}$, for the IGY traverse (Schytt, 1964), and of $<250 \mathrm{~m}$, falling to $<30 \mathrm{~m}$ over central Austfonna (Fig.1b), for our own work, are largely responsible for these discrepancies. On Vestfonna, the lack of bottom echoes over the central area makes comparison with the IGY seismic work and a single Soviet RES flight line (Macheret, 1981; Macheret and Zhuravlev, 1982) difficult, although the few coincident measurements available indicate differences of less than $5 \%$ of ice depth.

\section{CONCLUSIONS}

Airborne geophysical investigations of the ice caps of Nordaustlandet, during spring 1983, yielded a comprehensive data set on ice surface elevation, bedrock morphology and ice thickness. SPRI Mk. IV $60 \mathrm{MHz}$ RES equipment was used, in conjunction with a digital recording system, which made data reduction significantly more rapid than using traditional, analogue, recording methods. Where two or more ground transponders were received, navigation was also significantly more accurate $( \pm 30 \mathrm{~m})$ than in previous airborne RES surveys of large ice masses. The reduced geophysical information is held as a direct access computer database.

The results of these airborne geophysical investigations are presented here as a series of maps of the morphology of the Nordaustlandet ice caps. This information is being used in a number of wider cartographical and geophysical applications. Ice surface elevations provide a principal data source in the complete revision of official Norwegian maps of Nordaustlandet. Glaciological applications of this ice cap morphological information include the calculation of basal shear stresses over the ice caps and the comparison of observed with theoretical ice surface profiles along flow lines (Dowdeswell, 1984). More detailed mathematical, modelling studies of the dynamics of the Nordaustlandet ice caps must, however, await further field observations on the thermal regime, mass balance and distribution of velocities over the ice caps to complement the data presented above.

\section{ACKNOWLEDGEMENTS}

We thank Store Norsk Spitsbergen Kullcompani for logistical assistance and the British Antarctic Survey for the loan of a Twin Otter aircraft. SPRI funding was through UK NERC Grant GR3/4463 to DJD and a Studentship to JAD. Collaborative meetings were funded through a NATO grant.

\section{REFERENCES}

Cooper A P R, Drewry D J, Jordan S R 1983 Geophysical database and Antarctic coastline compilation. In Drewry D J (ed) Antarctica: glaciological and geophysical folio. Cambridge, University of Cambridge. Scott Polar Research Institute: Sheet 4

Crary A P, Robinson E S, Bennett H F, Boyd W W Jr 1962 Glaciological studies of the Ross Ice Shelf, Antarctica, 1957-1960. IGY Glaciological Report 6

Dowdeswell J A Unpublished Remote sensing studies of Svalbard glaciers. (PhD thesis, University of Cambridge, 1984)

Dowdeswell J A, Cooper A P R 1986 Digital mapping in polar regions from Landsat photographic products: a case study. Annals of Glaciology 8:

Dowdeswell J A, Drewry D J 1985 Place names on the Nordaustlandet ice caps, Svalbard. Polar Record 22(140): 519-523

Dowdeswell J A, Drewry D J, Liestøl O, Orheim O 1984[a] Airborne radio echo sounding of sub-polar glaciers in Spitsbergen. Norsk Polarinstitutt. Skrifter 182

Dowdeswell J A, Drewry D J, Liestøl O, Orheim O 1984[b] Radio echo-sounding of Spitsbergen glaciers: problems in the interpretation of layer and bottom returns. Journal of Glaciology 30(104): 16-21

Drewry D J, Liestøl O 1985 Glaciological investigations of surging ice caps in Nordaustlandet, Svalbard, 1983. Polar Record 22(139): 359-378
Ekman S R 1971 Seismic investigations on the Nordaustlandet ice caps. Geografiska Annaler 53A(1): $1-13$

Evans S, Smith B M E 1969 A radio echo equipment for depth sounding in polar ice sheets. Journal of Scientific Instruments Ser 2, 2: 131-136

Liestøl O 1969 Glacier surges in west Spitsbergen. Canadian Journal of Earth Sciences 6(4, Pt 2): 895-897

Macheret Yu Ya 1981 Forms of glacial relief of Spitsbergen glaciers. Annals of Glaciology 2: 45-51

Macheret Yu Ya, Zhuravlev A B 1982 Radio echo-sounding of Svalbard glaciers. Journal of Glaciology 28(99): 295-314

Schytt V 1964 Scientific results of the Swedish glaciological expedition to Nordaustlandet, Spitsbergen, 1957 and 1958. Geografiska Annaler 46(3): 243-281

Schytt V 1969 Some comments on glacier surges in eastern Svalbard. Canadian Journal of Earth Sciences 6(4, Pt 2): $867-873$

Smith B M E, Evans S 1972 Radio echo sounding: absorption and scattering by water inclusions and ice lenses. Journal of Glaciology 11(61): 133-146

Solheim A, Pfirman S L 1985 Sea-floor morphology outside a grounded, surging glacier; Brảsvellbreen, Svalbard. Marine Geology 65: 127-143 